\title{
東南アジアにおけるリモートセンシングの利用と将来の展望
}

\section{Utilization of Remote Sensing and its Prospect in South East Asia}

\author{
スーウィット・ウィブーンセート* \\ Suvit Vibulsresth
}

\begin{abstract}
概 要：東南アジアにおいては, 人口急増, 農業増産, 熱帯林破壊, 土壤侵食, 水資源枯渇などの問題を抱えており, 資源管理および開発計画にリモートセンシングの有効利用が期待されている。インド，タイおよびインドネシアには既に LANDSAT 受信局が建設され，LANDSATデータの利用が图られているが，未だに単純な段階の利用にとどまっており， 今後地理情報システム (GIS) との結合などリモートセンシングの高度利用を導入し, 上記諸問題を解決するための手法と して, 東南アジアの発展のために役立たせたいと考える。このたび, 日本学術振興会 (JSPS)の支援により, 昭和61年末か ら昭和62年初为まで約 2 ケ月間滞日する機会に恵まれたので, 日本写真測量学会に入会し, 会員諸兄に東南アジアにおける リモートセンシングの現状と将来の展望を以下に紹介する次第である。
\end{abstract}

\section{1. 東南アジアにおける諸問題}

東南アジアにおいては以下にのべるような多くの問 題に㥗まされている。

（1）人口急增

現在世界の人口は 48 億人であり, 年平均増加率は $1.7 \%$ である。この増加率は約 40 年で 2 倍になる速度で ある。東南アジアにおいては $2 \%$ をこえる国が殆んで

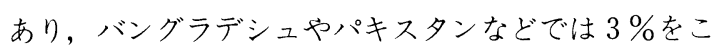
える速度である。インドは現在 7 億であるが, 約 $2.2 \%$ の増加率であるので, このまま増加を続けると, 今世 紀末には約10億に近づき, 30 年後には倍の14億になり， 50 年後には 20 億になる。著者の住む夕イはこれほど深 刻ではないが, 政治不安の影響でラオスおよびカンボ ジヤからの難民流入が多く，社会問題となっている。 また農村から都市への移動が激しく，都市の巨大化の 速度が都市の基盤整備の速度を超之環境悪化が進行し ている。

(2) 農産物の不足

アジアは世界の殼物総生産量約150億トンのうち,半 分以上の 80 億トンを輸入する食料不足大陸である。し かし, 農耕地の増加率は平均して $1 \%$ 以下にしかすぎ

* Director, Remote Sensing Division National Research Council of Thailand 「写真測量とリモートセンシング」vol.26, No.1, 1987 $-8-$
ず，人口増加率より低い。このことは化学肥料や農薬 により反当り収量を増加させる，いわゆる掠奪農業を 強いることになり，一方で土壤の質の低下を招き土壤 侵食の一因となる。インドネシアにおいては，ジャワ 島に集中している人口を他の多くの島に人口を分散さ せる政策を取っており, 農業開発適地の選定が急務と なっている。

(3) 森林破壊

東南アジアにおいては, インドネシア, タイ, マレー シアが木材輸出国であり，日本が最大の木材輸入国で ある。夕イの例をあげると，世界第 2 次大戦前は夕イ の森林面積は約70\%であった。表 1 に示すように, 1961 年には写真判読により $53.3 \%$ の森林面積があった。 LANDSAT MSS 画像の判読により1973年に $43.2 \%$, 1978年に $34.2 \% ， 1982$ 年に $30.5 \%$ であり，1985年には $29.1 \%$ と遂に30\%を割ってしまった。タイ北部のみが 約 $50 \%$ の森林面積を有し,他の地域は $30 \%$ 以下であり, 東北部はわずか $15 \%$ しか残っていない。著者は, 健全 な国として森林面積は最低 $30 \%$ を有しているべきであ ク，20\%は赤信号であり，10\%を切れば絶望的状態と 考える。タイは現在まさに危険信号が点灯していると いえる。悲しいことにタイ北部はこの 24 年間に $19.0 \%$ の減少があり，この速度で減少が続けば30年後には $50 \%$ から $30 \%$ に減少することになる。他の地域は森林 を切りつくし，伐採が困難なところのみにしか森林が 残されていない状況となっている。インドネシアおよび マレーシアについても,タイとほぼ同様な傾向である。 
表 1 タイ国における森林面積の減少

\begin{tabular}{|c|c|c|c|c|c|c|c|c|c|c|c|c|}
\hline \multirow{2}{*}{ 地 域 } & \multicolumn{2}{|c|}{$\begin{array}{r}1961 \text { (Air-PHOTO } \\
1: 60,000)\end{array}$} & \multicolumn{2}{|c|}{$\begin{array}{c}1973 \\
(\text { LANDSAT - } 1)\end{array}$} & \multicolumn{2}{|c|}{$\begin{array}{c}1976 \\
\text { (LANDSAT-2) }\end{array}$} & \multicolumn{2}{|c|}{$\begin{array}{c}1978 \\
(\text { LANDSAT-2) }\end{array}$} & \multicolumn{2}{|c|}{$\begin{array}{c}1982 \\
\text { (LANDSAT-3) }\end{array}$} & \multicolumn{2}{|c|}{$\begin{array}{c}1985 \\
(\text { LANDSAT - 4,5) }\end{array}$} \\
\hline & 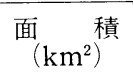 & $\%$ & $\begin{array}{l}\text { 面 積 } \\
\left(\mathrm{km}^{2}\right)^{-}\end{array}$ & $\%$ & $\begin{array}{l}\text { 面 } \\
\left(\mathrm{km}^{2}\right)^{\text {積 }}\end{array}$ & $\%$ & 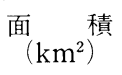 & $\%$ & 面 $\left(\mathrm{km}^{2}\right)^{\text {積 }}$ & $\%$ & 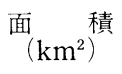 & $\%$ \\
\hline 北 部 & 116,275 & 68.54 & 113,595 & 66.96 & 102,327 & 60.32 & 94,937 & 55.96 & 87,756 & 51.73 & 84,126 & 49.59 \\
\hline 東 部 & 21,163 & 57.98 & 15,036 & 41.19 & 12,631 & 34.60 & 11,037 & 30.24 & 8,000 & 21.92 & 7,990 & 21.89 \\
\hline 東北部 & 70,904 & 41.99 & 50,671 & 30.01 & 41,494 & 24.57 & 31,221 & 18.49 & 25,886 & 15,33 & 24,224 & 14.35 \\
\hline 中 部 & 35,660 & 52.91 & 23,970 & 35.56 & 21,826 & 32.38 & 20,426 & 30.31 & 18,516 & 27.47 & 17,228 & 25.56 \\
\hline 南 部 & 29,626 & 41.89 & 18,435 & 26.07 & 20,139 & 28.48 & 17,603 & 24.89 & 16,442 & 23.25 & 15,485 & 21.90 \\
\hline 全 国 & 273,628 & 53.33 & 221,707 & 43.21 & 198,417 & 38.67 & 175,224 & 34.15 & 156,600 & 30.52 & 149,053 & 29.05 \\
\hline
\end{tabular}

\begin{tabular}{|c|c|c|c|}
\hline \multirow{2}{*}{\multicolumn{2}{|c|}{ 地 域 }} & \multicolumn{2}{|c|}{24 年間の減少 } \\
\hline & & 面 積 & $\%$ \\
\hline 北 & 部 & 32,149 & 18.95 \\
\hline 東 & 部 & 13,173 & 36.09 \\
\hline 東 北 & 部 & 46,680 & 27.64 \\
\hline 中 & 部 & 18,432 & 27.35 \\
\hline 南 & 部 & 14,141 & 19.99 \\
\hline 全 & 国 & 124,575 & 24.28 \\
\hline
\end{tabular}

\section{（4）土壤侵食}

インド，パキスタンのような半乾燥地带においては 過䛢放牧，薪材伐採などにより，ネパールにおいては 山地造成により，タイ，スリランカ，インドネシアに おいては森林伐採，焼畑農業などにより土壤侵食がお きている。インドは最も深刻であり, 国土の約 3 分の 1 は荒地となっており土壤侵食の進行とともに一部で 砂漠化が憂慮されている。土壤侵食に伴なう土壤流出 は一方では海岸の河口部で大量の土砂堆積をもたら し, 別の問題を提起している。黄土高原の土壤侵食が 黄河の濁流を生じ河口部で年平均約 $20 \mathrm{~km}^{2} の$ 三角州を 形成しているのは，この問題の典型的な例といえる。

（5）水資源の不足

水源地域での森林破壤などによる保水機能の低下お よび下流の都市域の急激な膨張による流出率の増大に より，雨期においては洪水氾濫が頻発し，逆に乾期に おいては水資源が不足する。バンコクにおいては地下
水の過㮃利用により地盤沈下を誘発し，雨期における 恒常的な汇監をおこしている。

上にあげた問題以外にも数多くの問題があり，いず れもリモートセンシングを利用した問題解決が期待さ れている。四 1 から図 4 は典型的なアジアの問題を示 した衛星画像および地上写真である。

\section{2. 東南アジアにおけるリモートセンシン グの利用条件}

東南アジアにおいては，国土の資源に関する基本調 査が遅れている。このため天然資源に関する主題図の 整備が遅れている。このことが, 資源に関する現状把 握を遅らせ, 資源の乱伐を許す一因となり, 適切な資 源管理政策の立案を遅らせている。この問題の解決が リモートセンシングに最も期待されているところであ ク，各国とも国土の保全と健全な国土建設のための重 要な科学技術として位置づけている。

LANDSATデータは，国レベルまたは地域レベル の広域の実状を効果的に眺められる点で他の方法より 安価である。MSS デー夕は十分な解像力ではないとは いえ，マルチスペクトルであり，時系データでもある。 タイでは TM デー夕を近い将来受信可能であり, MSSの限界を改善してくれるであろう。

東南アジアにおいては, 次の 5 項目がリモートセン シングデータの利用にとって大切な条件となってい る。

(1) 既存地形図との重ね合せ

既存の 25 万分の 1 および 5 万分の 1 の地形図と重ね 


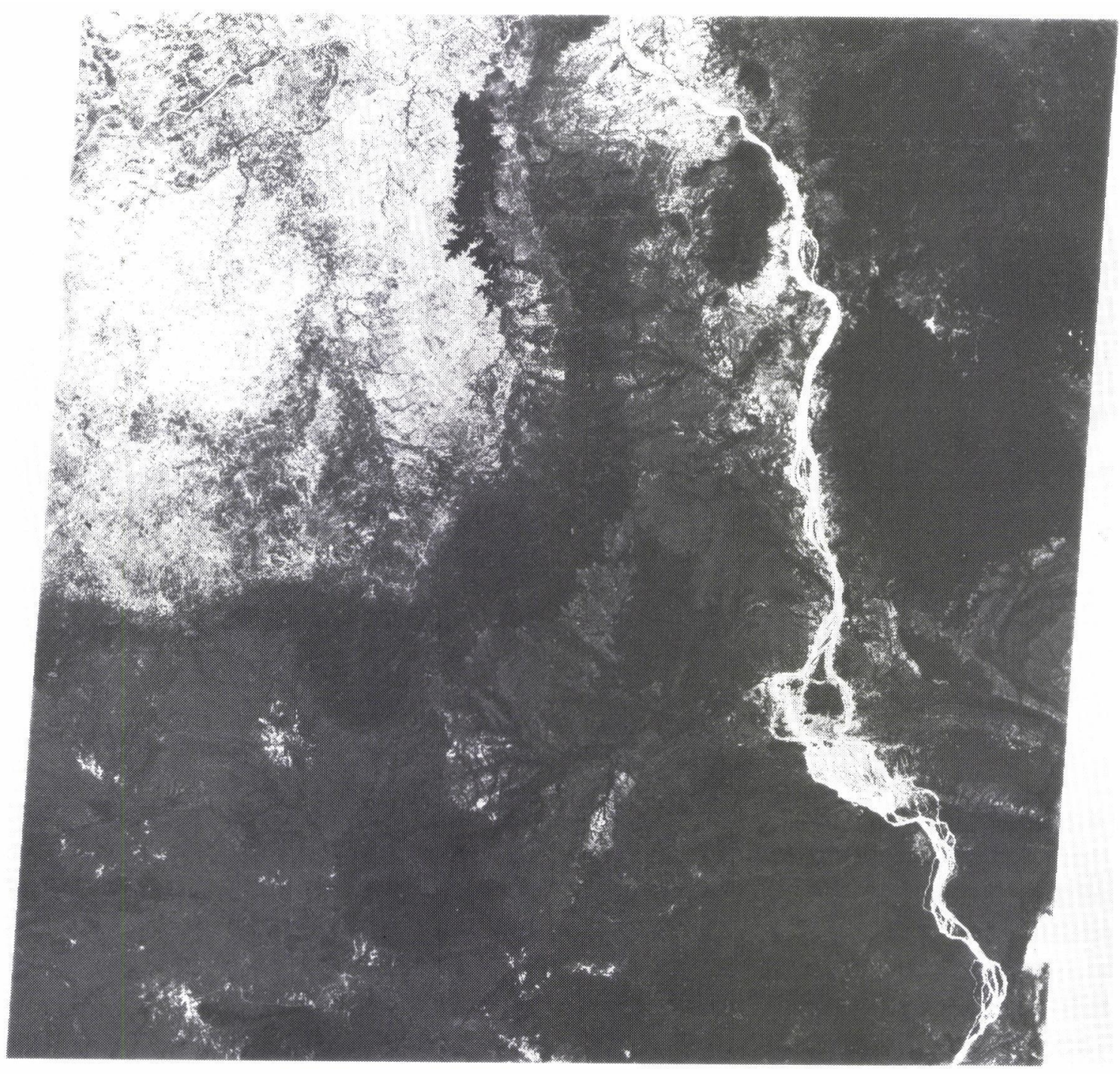

図 1 1983年12月 1 日に取った LANDSATー4の写真（バンド 5 )

左上部白い部分がタイ国領土であるが, 昔は森林が多かったが, 今は殆んど残っていない。そのすぐ南がカンボジヤ で森林が多く残っており (黒い部分) 右上から下へ流れるメコン川がよく見える。メコン川の右はラオスでカンボジ ヤと同様, 森林はたくさん残っている。 


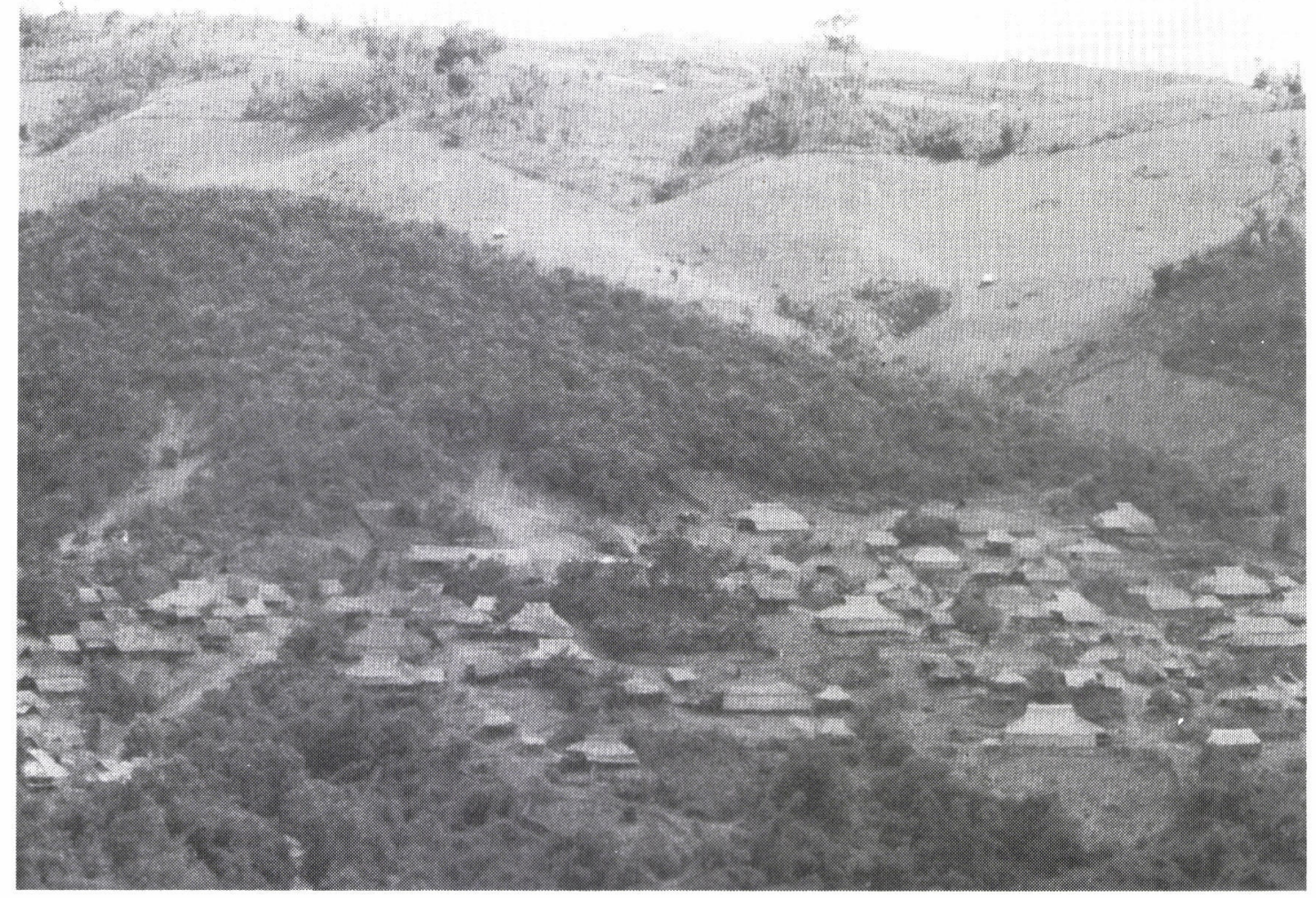

図2 タイ北部の風景

森林破壊の大きな原因の一つが焼畑農業である。

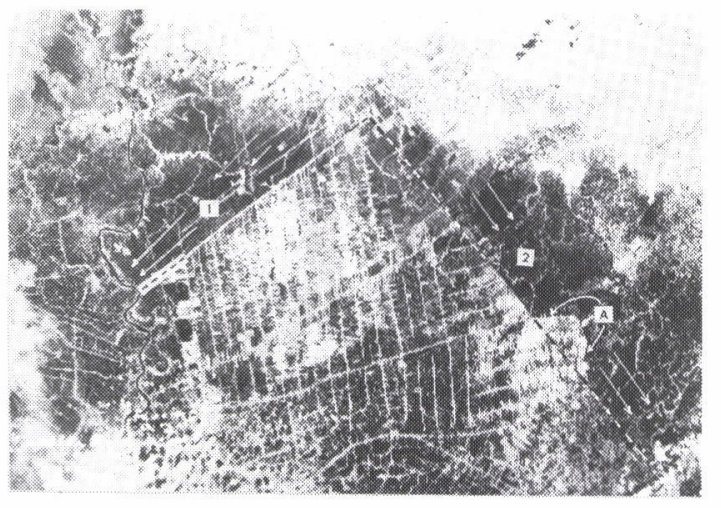

図 3 1983年11月初めの LANDSAT-4のバンド 7 のバ ンコク周辺の写真 洪水の氾濫跡がわかる

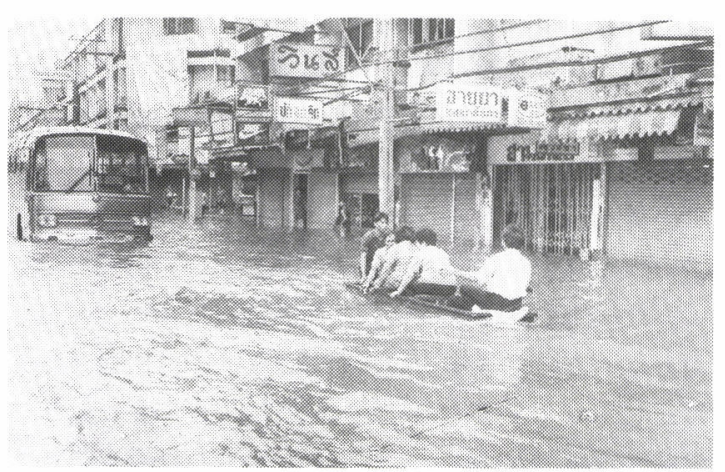

図4 1983年 9 月-11月の間のバンコク市の洪水の状態で ある 
合せられるような幾何補正および再配列が必要であ る。既存の地形図と同じ縮尺の主題図を判読により整 備する上で不可欠である。

(2) 高画質の写真の作成

多くの利用者は写真を利用した判読を行うので，い かに判読を助けるようなエンハンス画像を提供するか が重要である。判読の目的別に各種のエンハンスのメ ニューを整備しておく必要がある。

(3) 低価格なディジタル画像処理装置の普及

中大型の計算機システムは高価なため普及型のシス テムではない。普及を増進させるためにはパーソナル コンピュータを利用した低価格システムが必要であ $\eta ， こ の$ 分野での日本の協力を期待している。

（4）教育および研修の充実

人材の育成が急務となっている。大学での正課導入, 社会人の短期 $(3 \sim 6$ ケ月) 研修, セミナ一等の集会, 現地語の教科書作成, 本国人の教官育成など課題が山 積している。

(5) 研究開発に対する資金援助

東南アジア固有の問題に対する基礎研究を着実に進 めるための体制作りと同時に継続的な予算の支援が必 要である。その場限りの国際協力より, 継続性のある 地道な支援が強く望まれる。

東南アジアにおいては各種レベルの基本調査が遅れ ているのでリモートセンシングデー夕は, 種類および 解像力を問わずすべて有用である。

タイは日本の静止気象衛星の画像を利用できるが, 気象のみでなく海洋にも有効利用できる。NOAAの AVHRRのデー夕は無料であることから利用をさら に推進させる必要があろう。海洋污染の監視, 漁業情 報の提供などはNOAA 画像の良い利用分野である。 LANDSAT は特に陸域において有効であるが, アジ アの実状からすると受信料金(年額60万米ドル)とデー 夕の販売料金が高いといわざるをえない。SPOT 画像 は高分解能で画質が良いが, 同様に高価格である恼み がある。この点日本の打上げる MOS-1 は未だ価格が 確定していないが, 東南アジア諸国は受信料および デー夕価格とも無料ないしそれに近い低価格が設定さ れることを強く期待している。

スペースシャトルに搭載された画像レーダ（SIR 一A，B）により東南アジアの一部が撮像されたがきわ めて有用であった。熱帯雨林地帯には一年中雲におお われているところがあるので，レーダ画像は天候に左
右されずに画像が得られる点で光学センサーの補完的 役割として利用できる。

人工衛星画像の分解能は LANDSAT MSS で約 25 万分の $1, \mathrm{TM}$ で約 10 万分の 1 , SPOT HRV (10m) で無理してなんとか 5 万分の 1 の縮尺の地図に相当す る調査を可能にする。しかし, 実際の詳細な計画や管 理のためには航空写真による大縮尺の調査が必要であ る。しかし殆どの東南アジアの国では航空写真は軍の 規制と厳しい管理のもとにのみ利用可能であるので広 く民間レベルでの利用はできない。この意味で衛星 データによる研究開発は, 民間レベルおよび国際協力 レベルでも容易であり，将来の発展性がある。

\section{3.タイにおけるリモートセンシングの 利用}

タイにおけるリモートセンシングの簡単な歴史をの べる。1971年 9 月に省庁間リモートセンシング連絡調 整委員会 (National Remote Sensing Coordinating Committee）が設立された。これ以降すべてのリモー トセンシングに関する政府レベルの活動はこの委員会 で討議され，許認可が行われる。この委員会の議長は NRCT の事務局長 Dr. Choompol Iwasdiyakorn であ る。1972年に ERTS－1の主任研究者 (PI)，1973年に スカイラブ地球観測計画の PI，1975年に ERTSー 2 フォローオンの PIが夕イ国から認められた。1978年 には，科学技術およびエネルギー省が設立され，NRC もその翼下に入りリモートセンシング部が設立され, 著者がその責任者になった。

1979年 9 月に LANDSAT 地上局の建設が閣議で承 諾され，1981年11月にLANDSATおよびNOAAの 地上局が完成した。この間に1981年 6 月に GMS 地上 局が完成した。

1983年からは LANDSAT MSS データの国外配布 がはじまり，表 2 に示すように現在では海外からの データ利用は全体の約 $60 \%$ に達している。

1986年10月にはLANDSATのTMデータおよび フランスのSPOT データを受信するための契約が行 われ, 近い将来にこれらのデータ取得がはじめられる。 1986年11月には日本の打上げるMOS-1の受信局の 建設が閣議了承され12月に NRCT と NASDAの間で 覚え書き（MOU）が結ばれた。1987年10月頃にMOS -1 受信局がLANDSAT 受信局と同じ敷地内に建設 
表 2 過去 3 年間のタイ受信局の LANDSAT データ売り上げ

単位：米ドル

\begin{tabular}{|c|c|c|c|c|c|c|c|c|}
\hline \multirow{2}{*}{ 禾 } & \multirow{2}{*}{ 㓦 } & \multirow{2}{*}{ 者 } & 1984 & 年 & 1985 & 年 & 1986 & 年 \\
\hline & & & 額 & $\frac{\text { 度 }}{\%}$ & 額 & $\frac{\text { 度 }}{\%}$ & 金 & $\%$ \\
\hline 官 & & 庁 & 66,888 & 55.2 & 47,101 & 31.9 & 91,620 & 35.4 \\
\hline 法 & & 人 & 1,770 & 1.5 & 295 & 0.2 & 3,892 & 1.5 \\
\hline 国 & 際＼cjkstart機 & 関 (海外) & 42,146 & 34.8 & 94,813 & 64.3 & 162,164 & 62.8 \\
\hline 民 & 間 & 企 業 & 10,287 & 8.5 & 5,360 & 3.6 & 678 & 0.3 \\
\hline & 合 & 計 & 121,091 & 100.0 & 146,567 & 100.0 & 258,354 & 100.0 \\
\hline
\end{tabular}

\section{される予定である。}

以上に簡単な歴史をのべたが, 現在までのタイにお けるリモートセンシングの活動の特徵をのべると次の ようになる。

タイ国内では表 2 に示すように民間企業での利用は殆 ぞなく，政府機関による利用が主である。

（2）政府機関においては，本庁は調整役をしており， 試験研究機関が衛星デー夕の実際の利用を行ってい る。

（3）特に活躍している試験研究機関は次の 4 機関であ る。
i ) ナショナルリサーチカウンセル (NRC)

リモートセンシング部

ii）王立森林局森林管理部

リモートセンシング課

iii）農業経済局農業統計センター

リモートセンシング課

iv）土地開発局土地利用計画部

リモートセンシング課

以上が簡単な夕イにおける現状であるが, 次に近隣 諸国の活動を著者の知る範囲で紹介しよう。

インドネシアでは国土地理院（BAKOSUR-

TANAL）が地図の作成を担当しており衛星画像の利 用をしている。地形図等の作成用に航空写真の撮影を 軍とともに管轄しているのでリモートセンシングの研 究に有利な立場にある。しかし，宇宙関係は LAPAN が責任官庁であり，1984年には LAPAN の管理のもと にLANDSAT MSSの受信局が完成した。こ、には ディジタル画像処理装置も導入され今後充実するもの と期待される。公共事業省には, 日本の JICA の援助で 農業開発のためのリモートセンシングデー夕処理シス テム一式が供与され稼動中である。しかし農業以外の
目的の利用が認められていないため, 巾広い利用の阻 害となっていると聞いている。大学ではジョクジャカ ルタ大学でリモートセンシングの研究を行っており, リモートセンシングセンターがある。

フィリピンは1977年に天然資源管理センター (NRMC) が設立され, 当時ディジ夕ル画像処理装置で あった GE 社の Image 100 が導入された。1978年には ERIMの国際シンポジウムがマニラにおいて開催さ れ,フィリピンはアジアにおけるリーダー的存在で あった。しかしその後はマルコス政権の低迷とともに リモートセンシングも低迷をつづけ今日に至ってい る。

マレーシアは農林省農業開発研究所 (MARDI) や森 林省の研究所等で衛星画像の利用が図られているが, 未だに中心となる機関がない状態である。マラヤ大学 でリモートセンシングを研究しているが, 研究の端緒 についたところである。

SPOT データの代理店として TERRA CONTROL という民間企業が1986年に設立され，デー夕の処理お よび配布をはじめた。

国連のアジア太平洋経済社会委員会 (ESCAP) のも とに地域りモートセンシング計画 (RRSP) が設立され ており, 研修, パイロットプロジェクト, 人員交流, 情報交換などが精力的に行われている。この活動の一 つとして, 政府間咨問委員会 (Intergovernmental Consultative Committee： ICC)が設けられ, 東南ア ジア諸国の間の意志決定者レベルの調整や意志疎通が 困られている。

ASEAN の中に科学技術委員会 (COST) が設けられ ており，リモートセンシングに関する計画が近く始め られるものと期待されている。

バンコクにあるアジア工科大学（AIT）には地域り 
モートセンシングトレーニングセンター(ARRSTC) があり, 短期（4 ケ月）の研修がなされている。当初 アメリカの国際開発事業団 (USAID) の援助で設立さ れたのであるが，その後西独およびフランスの援助导 加えられている。研修はIBMのディジタル画像処理 システムを中心にして行われているが，研修修了者が 自国に帰国したあとコンピュータシステムがなく，研 修の成果をすぐに仕事に活用できないことが悩みと なっている。

カナダは研究レベルでの国際協力を進めるために, 国際開発研究センター (IDRC) を設立し, シンガポー ルに支所を有している。IDRCはりモートセンシング の研究にも積極的な支援をしており，マングローブ林 の調査研究のためにタイ, フィリピンおよびインドネ シアに 3 年間援助を行っている。

\section{4. 将来の展望}

人工衛星を利用したリモートセンシングは，アジア 地域において, 森林破壊, 砂漠化, 土地利用変化など グローバルな環境監視の技術として，ますます発展す ると考えられる。

このためには, NOAA AVHRRのように低分解能 でも広域を頻度多くデー夕収集する日常的監視機能 と, LANDSAT TM やSPOT HRV のように頻度は それほどないが高分解能画像を提供する機能の両者に よる多段的リモートセンシングが定着するものと考え られる。

東南アジアにおいてはASEANを通じて多国間の 協力システムを推進することが可能であり，リモート センシングの分野においてもデータの入手とその有効 利用について地域内での国際協力がますます進められ るであろう。

最後に著者が考えていることをのべて本稿の結論と したい。

(1) 東南アジアにおけるリモートセンシングの利用は 初期の簡単なレベルにある。大学および研究所を含 めて官民協力して高度利用のための研究および調整 を組織的にかつ継続的に推進する必要がある。

（2）日本は JICAにより毎年アジア諸国の技術者を育 成しているが，その数は十分ではない。夕イ側から
すると少なくとも今の 2 〜 倍に増加してほしい。 昭和61年度から科学技術仃が ASEAN 諸国との協 同プロジェクトを発足させた。このような人材育成, 協同プロジェクトおよび研究基盤援助はASEAN 諸国が日本に最も強く期待していることであり，今 後さらに充実されることを望む。

（3）宇宙開発事業団（NASDA）の協力によりタイに MOS-1受信局が設置されることになった。受信し たデータはタイには勿論のこと, 広くアジア諸国に 無料または超低価格で迅速に配布してくれることを 望む。LANDSAT やSPOT のデータの高価格がリ モートセンシングの普乃を阻害している。タイの LANDSAT 受信局においても60万ドルの受信料を 払い込んでいるのに対し，表 2 に示すように 25 万ド ルの売り上げしかなく不足分の予算を得るのに悩ま されている。

（4）リモートセンシングの資源管理への高度利用とし て地理情報システム (GIS) を導入することが必要で あるとの示唆を受けているが, 東南アジアに適した システムを確立するためには，その有効性を検証す る研究を早急に推進する必要がある。

\section{おわりに}

今回日本学術振興会の援助により東京大学生産技術 研究所村井研究室に 2 ケ月間在籍し, リモートセンシ ングの研究を行うことができた。2 ケ月の間に, 熊本 において東海大学の主催するアジア農業りモートセン シングシンポジウム, 盛岡において岩手大学の主催す る宇宙からのリモートセンシングデータの高度利用に 関するセミナ一，大阪に抏いて日本りモートセンシン グ協会の主催する地域りモートセンシングセミナーに 参加できた。また滞日中に NRCT と NASDA の間で 締結されたMOS-1受信局の MOU の調印に立ちあ うことができた。国土地理院および公害研究所の担当 者と科学技術庁の協同プロジェクトの打合せもでき た。RESTEC, NCM, 国際航業など技術的な視察もで きた。協力して下さった多くの日本の友人に謝意を表 したい。最後に日本語の原稿を監修して下さった村井 俊治教授に深甚な謝意を表わす。 